\title{
High incidence of oncogenic HPV genotypes found in women from Southern Brazil
}

\author{
Ludmila G Entiauspe ${ }^{1,2}$, Mariângela Silveira ${ }^{3}$, Emily M Nunes ${ }^{1}$, Suélen P Basgalupp ${ }^{1}$, \\ Dulce Stauffert $^{4}$, Odir A. Dellagostin ${ }^{1,2}$, Tiago Collares ${ }^{1,2}$, Fabiana K. Seixas ${ }^{1,2^{*}}$ \\ ${ }^{1}$ Grupo de Pesquisa em Oncologia Molecular e Celular, Centro de Desenvolvimento Tecnológico, \\ Universidade Federal de Pelotas, RS, Brasil. \\ ${ }^{2}$ Programa de Pós-Graduação em Biotecnologia, CDTec, Universidade Federal de Pelotas, \\ Pelotas, RS, Brasil. \\ ${ }^{3}$ Programa de Pós-Graduação em Epidemiologia, Universidade Federal de Pelotas, Pelotas, RS, Brasil. \\ ${ }^{4}$ Laboratório da Faculdade de Medicina, Universidade Federal de Pelotas, Pelotas, RS, Brasil.
}

Submitted: March 25, 2013; Approved: September 9, 2013.

\begin{abstract}
Oncogenic HPV genotypes are strongly associated with premalignant and malignant cervical lesion. The purpose was to determine human papillomavirus (HPV) prevalence and genotypes, and to estimate cervical cancer risk factor associations. Cervical samples were obtained from 251 women seeking gynecological care at the Pelotas School of Medicine Clinic. This is a cross-sectional study. HPV-DNA was amplified by nested-PCR using MY09/11 and GP5/6 primers, and the sequencing was used for genotyping. Sociodemographic and behavioral risk factors were obtained by closed questionnaire, and its relationship to HPV infection prevalence were analyzed. Statistical analyses were performed using SPSS 16.0 software, and differences were considered significant at $\mathrm{p}<0.05$. As results, the prevalence of HPV infection was $29.9 \%$. The most frequent genotype was HPV-16 (41.3\%), followed by HPV-18 (17.3\%), and HPV-33 (9.3\%). Others nine HPV genotypes were also found. On this population, prevalence of oncogenic HPV genotypes was high, but does not seem to confer relationship with the risk factors investigated. Future investigations in larger populations are necessary, for the proposition of more appropriated monitoring strategies and treatment according to the Brazilian health service reality, as well as patients.
\end{abstract}

Key words: HPV, SDT, molecular epidemiology, cervical cancer.

\section{Introduction}

The human papillomavirus (HPV) is one of the most common etiologic agent of sexually transmitted diseases, with high prevalence rates. Actually, more than $100 \mathrm{HPV}$ types have been described, of which 40 can infect the mucosa of the anogenital tract in both, men and women. According to their oncogenic potential, those viruses are classified as high- or low-risk genotypes (Bernard et al., 2010; De Villiers et al., 2011). The high-risk oncogenic genotypes are those that are strongly associated with premalignant and malignant cervical lesions, mainly HPVs 16 and 18, being also responsible for $70 \%$ of invasive cervical cancer (CC) cases in Brazil (Muñoz et al., 2006).
In Brazil, cervical cancer is the second most common type of cancer in the female population, and the fourth major cause of death in women. For 2012, 17.540 new cases were expected, 17 cases per 100,000 women (MS, 2011). Highly accurate techniques and epidemiologic studies demonstrate the relationship between the development of cervical cancer and HPV. HPV-DNA has been detected in $99.7 \%$ of cervical cancer cases worldwide (Fernandes et al., 2004).

Although HPV infection is considered an integral part of cervical cancer development, an association between HPV infection, oncogenic genotypes persistence, and other risk factors, determine the development of cervical intraepithelial neoplasia (CIN), and cervical cancer (Wang 
et al., 2010). The risk factors include youth, a high number of sexual partners throughout life, early sexual activity, tobacco smoking, low socioeconomic status, and genetic factors (Marlow et al., 2007; Kapeus et al., 2009; Louie et al., 2009), as well the 16 and/or $18 \mathrm{HPVs}$ genotypes infection, responsible for $70 \%$ of invasive cervical cancer (CC) cases in Brazil (Muñoz et al., 2006). In addition, infections caused by human immunodeficiency virus (HIV), bacterial vaginosis (BV), Trichomonas vaginalis (TV), and by Chlamydia trachomatis (CT) were involved as co-factors for cervical cancer development, adjuvants of the neoplastic process (King et al., 2011, Nam et al., 2009).

Based on these data, our study aimed to detect the prevalence of HPV infection, to identify HPV genotypes, and to analyze cervical cancer risk factors in a female population representative of Pelotas, Rio Grande do Sul, Brazil.

\section{Materials and Methods}

\section{Study population}

This is a cross-sectional study. From May 2010 to May 2011, 251 women seeking gynecologic care at the gynecological ambulatory clinic at the Pelotas Federal University School of Medicine (UFPel) fulfilling eligibility criteria (not pregnant, sexually active, and not menstruating), and agreeing to participate in the study, were sequentially selected. The study used a closed questionnaire adapted from a previous study (Silveira and Santos, 2006), applied by a female trained interviewer. Routine gynecological exams (cervicitis indicators, visual inspection with acetic acid and Lugol's iodine), were realized, and included in the questionnaire, as well the patient's recorded information (last Pap test result).

The study was approved by the Ethics Committee of the Faculty of Medicine - Federal University of Pelotas in June 2009, and informed consent was obtained from all participants. All procedures were carried out in accordance with the guidelines of the Helsinki Declaration.

\section{Sample collection and processing}

Two cervical samples were collected from each patient. The first, with an Ayre's spatula was placed on slides for Bacterial vaginosis (BV) and Trichomonas vaginalis (TV) analysis by the Gram method. The second sample was collected with a cytobrush, and placed into $1.5 \mathrm{~mL}$ eppendorf tubes containing $300 \mathrm{~mL}$ of Cell Lysis Solution (Puregene $^{\mathrm{TM}}$ DNA Extraction Kit, Gentra Systems Minneapolis, MN). The tubes were submitted to digestion using $1.5 \mu \mathrm{L}$ of Proteinase $\mathrm{K}(10 \mathrm{mg} / \mathrm{mL}$, New England Biolabs, $\mathrm{MA}$ ), and incubated overnight at room temperature. The genomic material (DNA) was extracted, according to manufacturer specifications. As control for extracted DNA quality, the human TP53 gene PCR was performed, using the primers previously described (Lin et al., 2008). PCR were performed in a final reaction volume of $12 \mu \mathrm{L}$, and was carried out with one cycle $94{ }^{\circ} \mathrm{C}$ for $3 \mathrm{~min}$, followed by 40 cycles at $94^{\circ} \mathrm{C}$ for $30 \mathrm{~s}, 57^{\circ} \mathrm{C}$ for $30,72^{\circ} \mathrm{C}$ for $30 \mathrm{~s}$ and a final extension for $3 \mathrm{~min}$ at $72{ }^{\circ} \mathrm{C}$ (Thurow et al., 2011).

HPV detection was carried out using nested-PCR (nPCR) technique, which is performed in two rounds: the first using MY09/11 primers (Manos et al., 1989) and amplifying a $450 \mathrm{pb}$ fragment, the second used GP5/6 internal primers (Snijders et al., 1990), which amplify the $140 \mathrm{pb}$ fragment. The MY90/11 PCR reaction was performed in a final volume of $25 \mu \mathrm{L}$, and the conditions were as follows: 40 cycles of denaturation $\left(1 \mathrm{~min}\right.$ at $\left.95^{\circ} \mathrm{C}\right)$, annealing $(1 \mathrm{~min}$ at $55^{\circ} \mathrm{C}$ ), and extension $\left(1 \mathrm{~min}\right.$ at $\left.72{ }^{\circ} \mathrm{C}\right)$ (Gravitt et al., 2000 ). In the second round, the conditions were 40 cycles of denaturation $\left(30 \mathrm{~s}\right.$ at $\left.94^{\circ} \mathrm{C}\right)$, annealing $\left(30 \mathrm{~s}\right.$ at $\left.45^{\circ} \mathrm{C}\right)$, and extension $\left(30 \mathrm{~s}\right.$ at $72^{\circ} \mathrm{C}$ ) (Husnjak et al., 2000). Both PCR reactions were preheated for $9 \mathrm{~min}$ at $95^{\circ} \mathrm{C}$, and a final extension for $5 \mathrm{~min}$ at $72^{\circ} \mathrm{C}$. All PCR products were visualized on a $2.0 \%$ agarose gel with GelRed ${ }^{\mathrm{TM}}$ (Biotium Inc., CA).

\section{HPV sequencing}

HPV positive PCR products were purified previously using the Gel Band purification kit (GE Healthcare, USA) according the manufacturer instructions. The sequencing was performed in a MegaBACE 1000 DNA sequencer (GE Healthcare, USA), using Dynamic ET-terminator technology. Chromatograms were assembled and analyzed using the ContigExpress ${ }^{\circledR}$ module of the Vector NTI 10.0 suite (Invitrogen, USA). The assembled sequences were submitted to BLAST alignment (www.nci.nlm.gov/BLAST), against sequences available in GenBank.

\section{Statistical analyses}

Chi-square $\left(\chi^{2}\right)$ test was used to evaluate the association between HPV presence (and their HR/LR genotypes) with the variables of questionnaire. A multivariate analysis was made using logistic regression applied to a hierarchical model. The analysis was performed using SPSS 16.0 software (SPSS, Chicago, IL). Differences were considered significant at $\mathrm{p}<0.05$.

\section{Results}

Four hundred women were approached to participate, but only 251 were considered eligible for the study. The mean age was 33.3 years old (median 34 years old), ranging from 18 to 45 years old. Most of the samples did not present endocervical mucupurulent discharge $(77.2 \%)$, friability (70.8\%), or cervical motion tenderness $(84.6 \%)$. The visual inspection with acetic acid (VIA) and visual inspection with Lugol's iodine (VILI) were negative for sub-clinical lesions in $85.9 \%$ and $71.1 \%$ of the participants, respectively. The Gram test detected BV in $9.2 \%$ of the women, and TV in $2.8 \%$. Of the Pap smear results, $54.2 \%$ were normal, $38.6 \%$ inflammatory, $0.8 \%$ with ASCUS, $0.4 \%$ 
showed presence HPV, $2.1 \%$ indicated NIC I, and $0.4 \%$ indicated NIC II. Colposcopies were abnormal in $5 \%$ of the participants (data not show). The behavioral and sociodemographic characteristics are showed on Table 1. HPV was detected in $29.9 \%(\mathrm{~N}=75)$, HR-HPV in $25.3 \%$, and LR-HPV in $2.9 \%$ of the samples (Table 2). The most frequent genotype was HPV-16 (41.3\%), followed by HPV-18 (17.3\%), and HPV-33 (9.3\%). The genotypes HPV-6 (2.7\%), -31 (2.7\%), -43 (1.3\%), -45 (1.3\%), -54 (4.0\%), -56 (4.0\%), -58 (4.0\%), -70 (1.3) and -81 (2.7\%) were also found. Six samples $(8.0 \%)$ could not classified by sequencing due to overlap of the sequence-peaks. These were categorized as HPV-X (Figure 1).
The bivariate analyses didn't show statistic significance in relation to behavioral characteristics, although it was observed that HPV infection occurred mostly in women who were ex-smokers (35.5\%), had consumed alcohol at least once a week (34.9\%), had never been pregnant $(45.7 \%)$, began sexual activities between $13-15$ years of age (35.4\%), had from 2 to 4 sexual partners in life (26.9\%), had STD detected in the last 12 months (35.3\%), and whose last Pap test was in less than 3 years $(32.3 \%)$. Cervicitis indicators showed that $30.1 \%$ of the samples did not present endocervical mucupurulent discharge, or friability at (31.6\%); cervical motion tenderness was observed in $31.6 \%$ of the women (Table 3). The VIA inspection was positive in $34.3 \%$ of the participants, and VILI inspection

Table 1 - Distribution of socioeconomic, demographic and behavioral characteristics.

\begin{tabular}{|c|c|c|c|}
\hline Variable & $(\%)$ & Variable & $(\%)$ \\
\hline Age (years) & & Current smoker & 19.9 \\
\hline $18-24$ & 17.5 & Ex-smoker & 24.7 \\
\hline $25-30$ & 21.9 & Never smoker & 55.4 \\
\hline $31-35$ & 17.9 & Alcohol consume (last 4 weeks) & \\
\hline $36-39$ & 19.9 & At least once a week & 17.1 \\
\hline $40-45$ & 22.7 & Less than once a week & 29.5 \\
\hline Skin color & & Never & 53.4 \\
\hline White & 65.7 & Pregnancy & \\
\hline Black & 12.4 & Yes & 81.7 \\
\hline Others & 21.9 & No & 18.3 \\
\hline Reading ability & & Use of condom (in life) & \\
\hline Yes & 98.0 & Yes & 90.0 \\
\hline No & 2.0 & No & 10.0 \\
\hline Schooling (years) & & Sexual activity began (years) & \\
\hline 0 & 2.0 & $\leq 12$ & 2.8 \\
\hline $1-4$ & 12.9 & $13-15$ & 33.1 \\
\hline $5-8$ & 37.5 & $16-18$ & 49.8 \\
\hline $9-11$ & 14.9 & $\geq 19$ & 14.3 \\
\hline$\geq 12$ & 32.7 & Sexual partners (in life) & \\
\hline Marital status & & 1 & 30.8 \\
\hline Married/consensual union & 81.3 & $2-4$ & 44.4 \\
\hline Single & 11.2 & $5-8$ & 15.2 \\
\hline Separated/divorced/widowed & 7.6 & $\geq 9$ & 9.6 \\
\hline Live alone & & STD detection (last 12 months) & \\
\hline Yes & 2.8 & Yes & 6.8 \\
\hline No & 97.2 & No & 93.2 \\
\hline Family Income (minimum wages) & & Last Pap test & \\
\hline $0-1$ & 25.5 & Never & 4.4 \\
\hline 2 & 41.3 & $<3$ years & 74.9 \\
\hline 3 & 23.5 & $>3$ years & 15.1 \\
\hline$\geq 4$ & 9.7 & Don't remember & 5.6 \\
\hline
\end{tabular}

Cigarette smoking 
Table 2 - HPV detection and oncogenic potential.

\begin{tabular}{lcc}
\hline Variables & Number & $(\%)$ \\
\hline HPV & 251 & \\
Positive & & 29.9 \\
Negative & & 70.1 \\
HPV oncogenic potential & $69 *$ & \\
High risk & & 89.9 \\
Low risk & & 10.1 \\
\hline
\end{tabular}

*HPV positives by nPCR.

in $29.6 \%$. The presence of BV and TV was observed for $31.8 \%$ and $28.6 \%$ of the patients respectively. The cytological results for HPV presence, and NIC II was confirmed by $\mathrm{nPCR}$ for all $(\mathrm{p}=0.362)$. The colposcopy results were abnormal in $41.7 \%$ of the HPV positive cases $(p=0.379)$. In relation to high or low risk HPV infection, and variables, it was observed that all high risk HPV infections showed a direct association (100\%) with NIC I and NIC II Pap test results $(\mathrm{p}=0.470)$. No statistical difference was also found in the multivariate analyses (data not show).

\section{Discussion}

Brazil has a population of 69.14 million women who are at risk for cervical cancer development, and current estimates indicate that $14.1 \%$ of the women in the general population have harbored a cervical HPV infection at some time in their lives. A total $70.7 \%$ of invasive cervical cancers are attributed to HPV-16 or -18 (WHO, 2010). HPV infection prevalence in Brazil varies between $7 \%$ and $43 \%$, according to a systematic review of the literature performed in four Brazilian regions (Ayres and Silva, 2010). In this study, the prevalence was within the expected range (29.9\%). Two other studies were realized in the same state in Southern Brazil: on the first was found a higher HPV infection prevalence $(60 \%)$ in HIV negative women, (with or without cervical lesions) than reported here (Entiauspe et al., 2010). In the second study Rosa et a.l (2008) found that HPV infection was lower (12.3\%). In the Northern regions, Noronha et al. (2011) conducted a screening study in 1021 women in the city of Belém, and observed an HPV prevalence of $12.4 \%$.

In this study, the most prevalent genotype was HPV-16, followed by HPV-18. These findings are consistent with Oliveira-Silva et al. (2011), which in a study performed in Rio de Janeiro (with PCR for DNA-HPV detection in $297 \mathrm{HPV}$ positive women), noted a prevalence of $28 \%$ for HPV-16, and $14.4 \%$ for HPV-18, differing by only a third from the most prevalent genotype, which was reported for HPV-45 (7.6\%), and in our study was observed for HPV-33 (9.3\%). However, Mendonça et al. (2010) carried out a study with 248 women in the city of Recife, and also observed that the HPV-33 genotype was the third most prevalent $(13.9 \%)$, a similar percentage to the present study. The high prevalence of oncogenic genotypes found in this study indicates the need for frequent monitoring, and suggests nPCR technique for DNA-HPV detection as an alternative to early identification of women at high risk for cervical cancer development. Previous studies have already demonstrated that the use of primers pair MY09/11 and GP5/GP6 in a nPCR assay increases the sensitivity of HPV detection compared with PCR assay (Seaman et al., 2010; Coser et al., 2011).

Recent data (Vigitel, 2011) show that there has occurred a large decrease in the number of smokers in Brazilian population, going from $16.2 \%$ in year of 2006 to less than $15 \%$ in 2011 . These data show that the state capital of Rio Grande do Sul, Porto Alegre, has the largest number of smokers (23\%), higher than the one found in this study. The survey research also identifies that there was an increase in Pap tests realized in the last three years $(89.6 \%)$ in women who had more than 12 years schooling. This study also observed a higher percentage of Pap tests realized during the same period ( $<3$ years), but didn't found a relation with higher schooling. Some studies correlate potential risk fac-

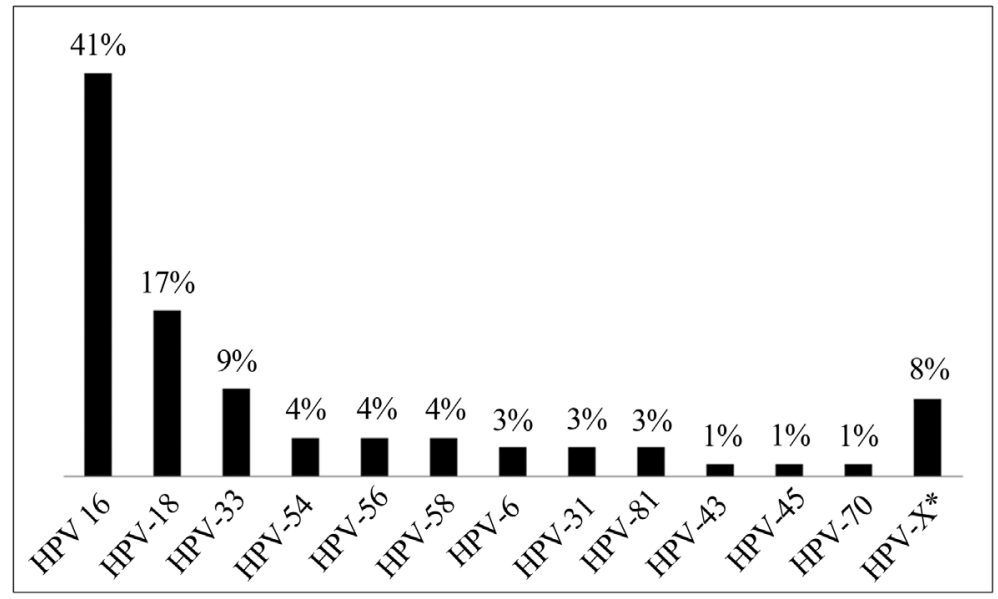

Figure 1 - HPV genotypes identified by sequencing. 
Table 3 - Frequency distribution of HPV infection according Cervicitis indicators, visual inspection, bacterial infection and Pap test results.

\begin{tabular}{lcc}
\hline Variables & \multicolumn{2}{c}{ HPV infection } \\
\cline { 2 - 3 } & Positive (\%) & Negative (\%) \\
\hline
\end{tabular}

Endocervical

mucupurulent dis-

charge

Yes

No

$$
28.1
$$

71.9

30.1

69.9

$\mathrm{p}=0.773$

Friablility

Yes

No

$$
26.0
$$

74.0

31.6

98.4

$\mathrm{p}=0.379$

Cervical motion ten-

derness

Yes

No

Visual inspection with acetic acid (VIA)

Positive

Negative

$$
34.3
$$

65.7

28.6

$\mathrm{p}=0.497$

\begin{tabular}{|c|c|c|}
\hline Positive & 29.6 & 70.4 \\
\hline \multirow[t]{2}{*}{ Negative } & 29.1 & 70.9 \\
\hline & $\mathrm{p}=0.946$ & \\
\hline \multicolumn{3}{|l|}{ Vaginosis } \\
\hline Positive & 31.8 & 68.2 \\
\hline \multirow[t]{2}{*}{ Negative } & 29.0 & 71.0 \\
\hline & $\mathrm{p}=0.783$ & \\
\hline \multicolumn{3}{|c|}{ Trichomonas vaginalis } \\
\hline Positive & 28.6 & 71.4 \\
\hline \multirow[t]{2}{*}{ Negative } & 29.3 & 70.7 \\
\hline & $\mathrm{p}=0.967$ & \\
\hline \multicolumn{3}{|l|}{ Pap test results } \\
\hline Normal & 28.1 & 71.9 \\
\hline Inflammatory & 34.1 & 65.9 \\
\hline ASCUS & 0 & 100.0 \\
\hline HPV & 100.0 & 0 \\
\hline NIC I & 40.0 & 60.0 \\
\hline NIC II & 100.0 & 0 \\
\hline \multirow[t]{2}{*}{ Inconclusive } & 25.5 & 75.0 \\
\hline & $\mathrm{p}=0.362$ & \\
\hline \multicolumn{3}{|l|}{ Colposcopy } \\
\hline Normal & 29.7 & 70.3 \\
\hline \multirow[t]{2}{*}{ Abnormal } & 41.7 & 58.3 \\
\hline & $\mathrm{p}=0.379$ & \\
\hline
\end{tabular}

Visual inspection with Lugol's iodine (VILI) tors with HPV infection. In this study, it wasn't possible to observe this relationship. One of the explanations could be the increasing awareness of condom use and smoking health harms that may be contributed to these findings.

Since the study is clinical based, the results should be considered as preliminary, giving an indication of the high prevalence of HPV infection by oncogenic genotypes found in women from Pelotas, but not being capable of correlating the infection with behavioral and socio-demographic factors. Further population based studies from the same geographical area are needed. The current research helps to identify regional differences of HPV genotypes, given the large area and population differences exist in Brazil, and is a contribution to the medical care of the population of Pelotas and to research centers studying human papillomavirus.

\section{Acknowledgments}

The authors are grateful to Brazilian National Research Council (CNPq).

\section{Conflict of Interest}

None declared.

\section{References}

Ayres ARG, Silva GA (2010) Cervical HPV infection in Brazil: systematic review. Rev Sau Publ 44:963-974.

Bernard HU, Burk RD, Chen Z, Doorsaler K van, zur Hausen H, de Villiers EM (2010) Classification of papillomaviruses (PVs) based on 189 PV types and proposal of taxonomic amendments. Virology. 401:70-79.

Coser J, Boeira TR, Fonseca ASK, Ikuta N, Lunge VR (2011) Human papillomavirus detection and typing using a nested-PCR-RFLP assay. Braz J Infect Dis 15:467-472.

De Villiers EM, Fauquet C, Broker TR, Bernard HU, zur Hausen H. (2004) Classification of papillomaviruses. Virology 324:17-27.

Entiauspe LG, Teixeira LO, Mendonza-Sassi RA, Gonçalves CV, Gonçalves P, Martinez AMB (2010) Human papillomavirus: prevalence and genotypes found among HIV-positive and negative women at a reference center in the far south of Brazil. Rev Soc Bras Med Trop 43:260-263.

Fernandes APM, Gonçalves MAG, Simões RT, Quintana SM, Duarte G, Donadi EA (2004) Influência da infecção pelo HIV-1 sobre a presença do HPV em lesões do colo uterino. J Bras Doenças Sex Transm 16:21-25.

Gravitt PE, Peyton CL, Alessi TQ, Wheeler CM, Coutlee F, Hildesheim A, Schiffman MH, Scott DR, Apple RJ (2000) Improved amplification of genital human papillomaviruses. J Clin Microbiol 38:357-361.

Husnjak K, Grce M, Magdic L, Pavelic K (2000) Comparison of five different polymerase chain reaction methods for detection of human papillomavirus in cervical cell specimens. $\mathrm{J}$ Virol Methods 88:125-134.

Kapeu AS, Luostarinen T, Jellum E, Dillner J, Hakama M, Koskela P, Lenner P, Love A, Mahlamaki E, Thoresen S, Tryggvadottir L, Wadell G, Youngman L, Lehtinen M 
(2009) Is smoking an independent risk factor for invasive cervical cancer? A nested case-control study within Nordic biobanks. Am J Epidemiol 169:480-488.

King CC, Jamieson DJ, Wiener J, Cu-Uvin S, Klein RS, Rompalo AM, Shah KV, Sobel JD (2011) Bacterial vaginosis and the natural history of human papillomavirus. Infect Dis Obstet Gynecol 2011:319460.

Lin YC, Huang HI, Wang LH, Tsai CC, Lung O, Dai CY, Yu ML, Ho CK, Chen CH (2008) Polymorphisms of COX-2 -765G > $\mathrm{C}$ and $\mathrm{p} 53$ codon 72 and risks of oral squamous cell carcinoma in a Taiwan population. Oral Oncol 44:798-804.

Louie KS, de Sanjosé S, Diaz M, Castellsague X, Herrero R, Meijer CJ, Shah K, Franceschi S, Muñoz N, Bosch FX (2009) Early age at first sexual intercourse and early pregnancy are risk factors for cervical cancer in developing countries. Braz J Cancer 100:1191-1197.

Manos MM, Ting Y, Wright DK, Lewis AI, Broker TR, Wolinsky SM (1989) The use of polymerase chain reaction amplification for the detection of genital human papillomaviruses. Cancer Cells 7:209-214.

Marlow LA, Waller J, Wardle J (2007) Public awareness that $\mathrm{HPV}$ is a risk factor for cervical cancer. Braz $\mathrm{J}$ Cancer 97:691-694.

Mendonça VG, Guimarães MJB, Filho JLL, Mendonça CG, Martins DBG, Crovella S, Alencar LCA (2010) Infecção cervical por papilomavírus humano: genotipagem viral e fatores de risco para lesão intraepitelial de alto grau e câncer de colo do útero. Rev Bras Ginecol Obstet 32:476-485.

Ministério da Saúde do Brasil Instituto Nacional do Câncer (2011) Estimativas 2012: Incidência de Câncer no Brasil. INCA, Rio de Janeiro, $35 \mathrm{pp}$.

Muñoz N, Castellsague X, de Gonzalez AB, Gissmann L (2006) Chapter 1: HPV in the etiology of human cancer. Vaccine 24 (Suppl 3):S3-1-S310.

Nam KH, Kim YT, Kim SR, Kim SW, Kim JW, Lee MK, Nam EJ, Jung YW (2009) Association between bacterial vaginosis and cervical intraepithelial neoplasia. J Gynecol Oncol 20:39-43.

Noronha VL, Cruz EM, Pinho CN, Mello WA, Villa LL, Russomano FB (2011) Human Papillomavirus (HPV) in
Women Screened to Cervical Uterine Cancer, Belém - Pará Brazil. J Bras Doenças Sex Transm 23:5-11.

Oliveira-Silva M, Lordello CX, Zardo LMG, Bonvicino CR, Moreira MAM (2011) Human Papillomavirus in Brazilian women with and without cervical lesions. Virol J 8:p4.

Rosa MI, Fachel JMG, Rosa DD, Medeiros LRM, Igansi CN, Bozzetti MC (2008) Persistence and clearance of human papillomavirus infection: a prospective cohort study. Am J Obstet Gynecol 199:e617.

Seaman WT, Andrews E, Couch M, Kojic EM, Cu-Uvin S, Palefsky J, Deal AM, Webster-Cyriaque J (2010) Detection and quantification of HPV in genital and oral tissueas and fluids by real time PCR. Virology J 7:194.

Silveira MF, Santos IS (2006) Impact of an educational intervention to promote condom use among the male partners of HIV positive women. J Eval Clin Pract 12:102-111.

Snijders PJ, van den Brule AJ, Schrijnemakers HF, Snow G, Meijer CJ, Walboomers JM (1990) The use of general primers in the polymerase chain reaction permits the detection of a broad spectrum of human papillomavirus genotypes. J Gen Virol 71(Pt1):173-181.

Thurow HS, Haack R, Hartwig FP, Oliveira IO, Dellagostin AO, Gigante DP, Horta BL, Collares T, Seixas FK (2011) TP53 gene polymorphism: importance to cancer, ethnicity and birth weight in a Brazilian cohort. J Biosci 36:823-831.

Vigitel - Vigilância de Fatores de Risco e Proteção para Doenças Crônicas por Inquérito Telefônico, Ministério da Saúde do Brasil (2011) Sistema de Monitoramento de Fatores de Risco e Proteção para Doenças Crônicas Não Transmissíveis por meio de Inquérito Telefônico. Available on http://portal.saude.gov.br Acessed 01 Mar 2013.

Wang SS, Gonzalez P, Yu K, Porras C, Li Q, Safaeian M, Rodriguez AC, Sherman ME, Bratti C, Schiffman M, Wacholder S, Burk SD, Herrero R, Chanock SJ, Hildesheim A (2010) Common Genetic Variants and Risk for HPV Persistence and Progression to Cervical Cancer. PLOS ONE 5:e8667.

WHO/ICO Information Centre on HPV and Cervical Cancer (2010) Human Papillomavirus and Related Cancers in Brazil. Summary Report 2010. Available on http://www. who. int/ hpvcentre. Acessed on 01 Mar 2013.

All the content of the journal, except where otherwise noted, is licensed under a Creative Commons License CC BY-NC. 